\title{
Applying the Principle of the Best Interests of the Child: A Lesson Learned from Establishing Diversion and Restorative Justice Task Force in North Sumatera Province
}

\author{
Rosmalinda $^{1}$, N N Sirait ${ }^{2}$, Suhaidi ${ }^{3}$, E Ikhsan ${ }^{4}$ \\ Universitas Sumatera Utara, Medan, Indonesia \\ ${ }^{1}$ rosmalindarohan@gmail.com
}

\begin{abstract}
Article 3 Paragraph 1 of convention on the rights of the child (CRC) states that this principle should become the primary consideration of the judiciary in taking action concerning the rights of Anak yang Berkonflik dengan Hukum/AKH (the children in conflict with the law). This paper was based on an evaluation research conducted by using a normative and field study. Two diversion and restorative justice task forces in Medan and Deli Serdang Regency were involved in an in-depth interview and a focus group discussion. As a result, the study concludes that; (a) the presence of diversion and restorative justice task forces is important in applying the best interests of the child principle including for $\mathrm{AKH}$; (b) the two task forces use Sistem Pidana Perlindungan Anak/SPPA (juvenile justice system) as a reference in conducting diversion and restorative justice to implement the principle of the best interests of the child for AKH. As a recommendation, the task force team needs to enhance their capacity and coordination in conducting diversion and restorative justice to afford the best interests of the child especially the AKH.
\end{abstract}

Keywords: AKH, Justice, Child

\section{INTRODUCTION}

The principle of the best interests of the child is a fundamental principle of the basic child rights. It is mentioned in Article 3 of the Convention on the Rights of the Child (CRC) [1]. The application of the principle is mentioned clearly in the articles regulating the rights of the child, such as the rights of being not separated from the parents (Article 9), of alternative care (Article 20) and of the child being separated from the adult (Article 37c). [1] The principle should be applied to budgeting, policy and law making [2]. This means that every adult should consider the effect of his decision to the children [2]. Furthermore, the Committee on the Rights of the Child has mentioned that the principle consists of three concepts, namely a substantive right, a fundamental, interpretative legal principle and a procedural rule [3].

This principle is very important as a substantive right ensures that the fulfillment of the child right is an essential state obligation [3]. The state party obligation is defined in Article 4 of CRC including Anak yang Berkonflik dengan Hukum/AKH (the children in conflict with the law) [1]. Indonesia is a state party of the CRC since it ratified the CRC through a Presidential Decree No.36 of 1990 concerning The Ratification of the CRC. Therefore, Indonesia should apply the principle including to the AKH in order to perform its obligation. 
There are some AKH cases in Indonesia before 2014, two of them are the Raju and AAL cases. The court verdict were not reflected the implementation of the best interests of the child principle [4]. The community thought that the criminal court process is an inappropriate way to settle criminal disputes involving $\mathrm{AKH}$, especially for a petty crime [4]. In addition, the verdicts had affected the children's future. In that time, the court felt in impelementation the best interests of the child principle for AKH as stipulated in the United Nations (UN) Minimum Standard Rules for the Administration of Juvenile Justice (Resolution 40/33), which is known as the Beijing Rules [5].

Since August 1, 2014, Indonesia has issued a new law amending the Law No.3 of 1997 concerning Children Court. It is the Law No.11 of 2011 concerning the Sistem Peradilan Pidana Anak/SPPA (juvenile justice system) [6]. The SPPA regulates a protection system through a diversion and restorative justice mechanism. SPPA believes that the court is the last resort principle for AKH [7]. SPPA is the answer to AKH especially in protecting the child right although based on UNICEF brief information, there are some problems concerning AKH and its regulations [8].

To ensure the implementation of diversion and restorative justice, North Sumatra province especially Medan and Deli Serdang regency have established task forces. For Medan, there is a Mayor Regulation No.463/384.K/III/2016 while for Deli Serdang, there is a District Decree No.2283 of 2016 [9].

There are two questions is this study namely (a) how the principle of the best interest of the child applied for AKH in Indonesia?; (b) what is the roles of task forces on diversion and restorative justice in Medan and Deli Serdang in the implementation SPPA?

\section{METHOD}

The study was conducted using literature and field studies. In addition to the normative study, an in-dept interview and a focus group discussion were used to collect the data involving two diversion and restorative justice task forces in Medan and Deli Serdang Regency.

\section{RESULT and Discuss}

\subsection{The Principle of the best Interest of the Child and SPPA Law}

General comment on Article 3 Paragraph (1) on the principle of the best interest of the child provides a framework of the state obligation as stipulated in Article 4 covering an obligation; (a) to ensure that the principle shall be adjusted and applied consistently in every action taken by the public institutions particularly administrative and judicial processes either directly or indirectly affecting the child; (b) to make all judicial decisions and administration accentuating the principle; (c) to ensure that the principle has been assessed and taken as primary considerations in making a decision by every actors that care or affect the children [3].

The Law No.11 of 2011 concerning SPPA is a form of obligation in practicing the principle of the best interests of the child.[9] SPPA is developed at all stages of the legal process [9]. It facilitates the victim/family, perpetrator/family, and the society to do a diversion. Moreover, Article 1 Point 6 of SPPA defines that a restorative justice as a settlement of criminal cases involving perpetrators, victims, families of perpetrators/victims, and other concerned parties to meet and conduct a restoration, but not a revenge [10]. Arif Gosita states that a legal certainty should be searched to maintain child protection activities 
and to prevent fraud that brings undesirable negative consequences in the child protection [11]. Through diversion and restorative justice, the AKH will not have a stigma since they do not go through a judicial process [12]. Moreover, the community will be involved in the process and practice the common value voluntarily [12].

\subsection{Diversion and Restorative Justice Task Forces}

Starting from 2016, there were two local regulation concerning Diversion and Restorative Justice Task Forces. The first is a Major regulation No.463/384.K/III/2016 in Medan and the second is the local regulation No.2283 of 2016 in Deli Serdang.

These two regulations show that local governments seriously realize the best interests of the child principle for AKH. Furthermore, the local government works collaboratively with the law enforcement officers (LEO) and Civil Society Organization (CSO) in task force by using a Standard Operational Procedure (SOP) as a guidance. One of the state party obligations which can be implemented by the task force in applying the best interests of the child principle is; (a) to develop a local wisdom system in implementing the diversion; (b) to coordinate and assist the implementation of diversion and restorative justice; (c) to monitor the implementation of diversion and restorative justice; (d) to develop information and data base system on $\mathrm{AKH}$; and, (e) to report and evaluate the progress of diversion implementation with restorative justice to the heads of regions either in the district or in the city [13].

The findings show that LEO plays an important role in the implementation of Diversion. The implementation is based on the SPPA which also acts a reference of the SOP. An interview with the LEO in Medan and Deli Serdang reveals that the police were the initial facilitators in handling the diversion and restorative justice. Moreover, the informant mentioned that coordination among the task force team is significant to the success of diversion and restorative justice.

An important agency, also a member of the task force, is BAPAS (the correctional centers). BAPAS Class I Medan plays a very important role at district courts of Medan, Stabat, Binjai and Lubuk Pakam. The study reveals that the existence of BAPAS in accordance with the mandate of the SPPA Law as a supporting unit which is obliged to conduct a community research, guidance, supervision, and mentoring. In the context of the $\mathrm{CRC}$, the existence of BAPAS is the fulfillment of the state's obligation to ensure that the best interests of the child principle have been assessed and taken as a primary consideration in making the decision in the justice system for AKH.

However, Pusat Perlindungan Anak dan Studi/PKPA (Center for Child Protection and Study), a CSO which concerns on child rights, finds that the presence of the task force and the SOP in Medan and Deli Serdang has not been able to ensure that the justice system for AKH has been in accordance with a fair and child-friendly process [14]. In the end of 2016 and 2017, PKPA conducted a reflection of child right implementation, it states that less than $20 \%$ of AKH cases handled through a diversion. Similar data were also reported by BAPAS; there were 591 cases of AKH during 2017. Less than $50 \%$ of the cases can be solved through a diversion. This situation happens due to the lack of agreement between the perpetrator and the victim, no place for alternative child reintegration, and other factors. There is still a long way to ensure a diversion approach and fairness in justice [14]. 


\section{CONCLUSION}

The application of the best interest of the child principle for $\mathrm{AKH}$ is realized in the local level through the establishment of diversion and restorative justice task forces. The task force team must develop their capacity both by organizing training and conducting diversion and restorative justice. Furthermore, the task force team also needs a better coordination strategy to maximize the application of the best interests of the child principle for $\mathrm{AKH}$.

\section{REFERENCES}

[1] OHCR, "Convention on the Right of the Child," Convention on the Right of the Child. [Online]. Available: https://www.ohchr.org/en/professionalinterest/pages/crc.aspx.

[2] UNICEF, "Rights under the Convention on the Rights of the Child," UNICEF, 2014. [Online]. Available: https://www.unicef.org/crc/index_30228.html.

[3] UN CRC, "General comment No. 14 (2013) on the right of the child to have his or her best interests taken as a primary consideration (art. 3, para. 1).".

[4] F. Fathurokhman, "The Necessity of Restorative Justice on Juvenile Delinquency in Indonesia, Lessons Learned from the Raju and AAL Cases," Procedia Environ. Sci., vol. 17, pp. 967-975, 2013.

[5] OHCR, "United Nations Standard Minimum Rules for the Administration of Juvenile Justice ('The Beijing Rules') Adopted by General Assembly Resolution," United Nations Human Rights Office of The High Commissioner, $1985 . \quad$ [Online]. Available: https://www.ohchr.org/Documents/ProfessionalInterest/beijingrules.pdf.

[6] H. S. Asnawi, "Status Hukum dan HAM Anak dalam Sistem Peradilan Pidana Anak di Indonesia," J. Huk., vol. 12, no. 2, pp. 167-193, 2015.

[7] Law, "No.11/2014 concerning Child Criminal Justice System." .

[8] UNICEF, "The significance of child protection systems: key findings from a strategic mapping exercise in six provinces of Indonesia," UNICEF, 2008. [Online]. Available: https://www.unicef.org/indonesia/Issue_Brief_CP_Systems_Mapping_in_Indo nesia.pdf.

[9] A. Tarigan, P. Rosmalinda, and A. Husna, "Tantangan dan Harapan Gugus Tugas Diversi dan Keadilan Restoratif dalam Perlindungan Anak yang Berkonflik dengan Hukum di Kota Medan," in Proseding Seminar Ilmiah Nasional Dies Natalis USU, 2016, vol. 64, pp. 153-158.

[10] Badan Penelitian dan Pengembangan Hukum dan HAM, Penerapan Restorative Justice pada tindak pidana anak. Jakarta: Percetakan Pohon Cahaya, 2016.

[11] M. Gultom, Perlindungan Hukum Terhadap Anak dalam Sistem Peradilan Pidana Anak di Indonesia. Bandung: PT Refika Aditama, 2014.

[12] N. Rochaeti and P. Pujiyono, "Implementation Study of Restorative Justice for 
Juvenile Criminal Justice System by Customary Court in Mainland Sulawesi," IOP Conf. Ser. Earth Environ. Sci., vol. 156, p. 12044, May 2018.

[13] "Decree of Deli Serdang District Head (Bupati) No. 2283 year 2016 on implementation team of diversion forum and restorative justice in handling children in conflict with the law in Deli Serdang District." .

[14] PKPA, "Laporan Penelitian," 2018. 